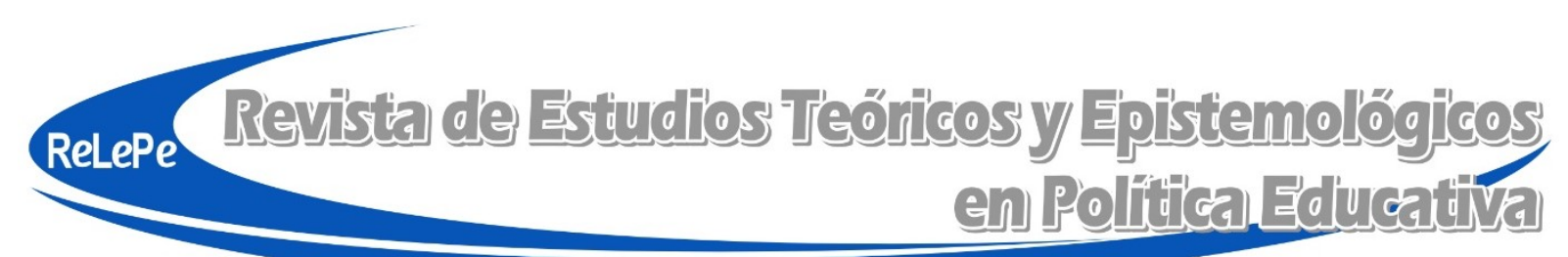

ISSN 2409-3696

doi) https://doi.org/10.5212/retepe.v.5.15036.007

\title{
Base Nacional Comum Curricular e o canto da sereia da educação normalizante: a articulação neoliberal-neoconservadora e o dever ético- estético da resistência
}

\author{
National Common Curricular Base and the Normalizing Education \\ Mermaid's chant: the neoliberal-neoconservative articulation and the \\ ethical-aesthetic duty of resistance
}

\author{
Base Curricular Nacional Común y el canto de la sirena de la educación \\ normalizadora: la articulación neoliberal-neoconservadora y el deber ético y \\ estético de la resistência
}

\author{
Bruno Antonio Picoli* \\ iD https://orcid.org/0000-0001-6831-2199
}

\begin{abstract}
Resumo: Este artigo procura compreender qual o significado educacional da Base Nacional Comum Curricular (BNCC) e reflete sobre qual pode ser o dever ético dos professores nesse cenário. O texto recorreu à pesquisa bibliográfica e documental e está organizado em seis partes. Na primeira, discute-se o processo de elaboração da BNCC. Na segunda, reflete-se sobre o conceito de Educação Normalizante em Gur-Ze'ev. Na terceira e quarta, respectivamente, procura-se identificar as influências neoliberais e neoconservadoras na BNCC. Na quinta, aborda-se como essa articulação operou no sentido de fazer da BNCC um projeto normalizante. Por fim, na sexta, reflete-se sobre o dever, ao mesmo tempo ético e estético, de resistir à BNCC. Conclui-se que a BNCC compreende uma radicalização da Educação Normalizante e que é justamente em razão da radicalização da normalização que se faz necessária a resistência ética e estética daqueles que ainda acreditam na educação.
\end{abstract}

Palavras-chave: BNCC. Educação normalizante. Neoliberalismo. Neoconservadorismo. Resistência.

\begin{abstract}
This paper seeks to understand the educational significance of the National Common Curricular Base (known in Brazil as Base Nacional Comum Curricular - BNCC) and reflects on what the ethical duty of teachers in this scenario could be. It used bibliographic and documentary research organized in six parts. In the first, the elaboration process of the BNCC is discussed. In the second, the reflection is on the concept of Normalizing Education in Gur-Ze'ev. In the third and fourth, respectively, it seeks to identify the neoliberal and neoconservative influences on the BNCC. In the fifth, it addresses on how the articulation operated to make the BNCC a normalizing project. Finally, in the sixth, it reflects on the duty, both ethical and aesthetic, to resist the BNCC. It concludes that the BNCC comprises a radicalization of Normalizing Education and it is precisely because of the radicalization of normalization that is needed the ethical and aesthetic resistance of those who still believe in education.
\end{abstract}

Keywords: BNCC. Normalizing education. Neoliberalism. Neoconservatism. Resistance.

\footnotetext{
* Professor da Universidade Federal da Fronteira Sul - Campus Chapecó. Doutor em Educação pela Pontifícia Universidade Católica do Rio Grande do Sul (PUC/RS). E-mail: <bruno.picoli@uffs.edu.br>.
} 
Resumen: Este artículo busca comprender cuál es el significado educativo de la Base Curricular Nacional Común (BNCC) y reflexiona sobre cuál puede ser el deber ético de los profesores en este escenario. Se recurrió a investigación bibliográfica y documental, organizada en seis partes. En la primera, se discute el proceso de elaboración de la BNCC. En la segunda, se reflexiona sobre el concepto de Educación Normalizadora en Gur-Ze'ev. En la tercera y cuarta, respectivamente, se busca identificar las influencias neoliberales y neoconservadoras en la BNCC. En la quinta, se enfoca cómo esta articulación actuó para hacer de la BNCC un proyecto de normalización. Finalmente, en la sexta, se reflexiona sobre el deber, al mismo tiempo ético y estético, de resistir a la BNCC. Se concluye que la BNCC comprende una radicalización de la Educación Normalizadora y que es justamente debido a la radicalización de la normalización que es necesaria la resistencia ética y estética de aquellos quienes todavía creen en la educación.

Palabras clave: BNCC. Educación normalizadora. Neoliberalismo. Neoconservadurismo. Resistencia.

\section{Introdução}

O que significa, em termos educacionais, a Base Nacional Comum Curricular (BNCC) e qual pode ser o dever ético dos professores nesse cenário? É a essa questão que se dedica essa reflexão. Para respondê-la, far-se-á uso de pesquisa bibliográfica, de documentos publicados pelo Ministério da Educação (MEC) e de manifestações, também públicas, de apoiadores da BNCC. O texto está organizado em seis partes. Na primeira, discute-se o processo de composição e de aprovação da BNCC. Na segunda, reflete-se sobre o conceito de Educação Normalizante em GurZe'ev e, por meio deste, a BNCC como radicalização da normalização. Nas terceira e quarta, procura-se identificar as influências de grupos político-econômicos na BNCC, respectivamente neoliberais e neoconservadores. Na quinta, aborda-se como a articulação entre esses grupos operou no sentido de fazer da BNCC um projeto normalizante e desumanizador. Por fim, à guisa de conclusões, reflete-se sobre o dever, ao mesmo tempo ético e estético, de professores e de professoras frente ao projeto desumanizante e normalizador dessa articulação.

\section{O processo de elaboração da BNCC: uma agenda marcada pela pressa e pelo antidiálogo}

Os apoiadores da ideia de uma Base Nacional afirmam que há, desde a Constituição Federal de 1988, a sua determinação legal. Eles sustentam que as reformas educacionais ocorridas na segunda metade da década de 1990, dentre as quais se destacam a Lei de Diretrizes e Bases (LDB), os Parâmetros Curriculares Nacionais (PCN) e as Diretrizes Curriculares Nacionais (DCN), corroboram isso. Sustentam, também, a imposição legal de uma Base a partir de metas do Plano Nacional de Educação (PNE) 2014-2024 (BARBOSA; SILVEIRA; SOARES, 2019; ANTUNES, 2019; SILVA; CANTARELLI, 2019). Entretanto, desde os primeiros movimentos para a composição do documento, diversas foram as manifestações de ressalvas e de oposição (BARBOSA; SILVEIRA; SOARES, 2019). Entidades salientaram ressalvas com o caráter deliberadamente acelerado nos prazos de cada etapa do processo de discussão e na própria sistematização das participações de professores, entidades críticas ou defensoras da base (ANPED, ABDC, 2015).

O período entre 2015 e 2018 - desde a submissão da versão preliminar da Base, elaborada em gabinete, para consulta pública até a divulgação da Versão Final com a inclusão do Ensino Médio - foi marcado por disputas políticas que fragilizaram a ordem democrática vigente, assim como abriram espaço para o crescimento do ultraconservadorismo e, mesmo, de apelos militaristas/ditatoriais (CALDEIRA NETO, 2016). Esses conflitos fizeram-se presentes durante a elaboração das diferentes versões do documento e incidiram na recomposição do Conselho Nacional de Educação (CNE), responsável pela sua homologação. Nesse interim, entidades também se retiraram por inteiro do processo (ANPUH, 2016). Além disso, com a reorganização 
dos Grupos de Trabalho entre a segunda e a terceira versão, somaram-se aos atores neoliberais, até então dominantes e aglutinados pelo Movimento pela Base, atores vinculados a movimentos e grupos ultraconservadores, especialmente pertencentes à Bancada Evangélica e ao Movimento Escola sem Partido. Na BNCC, encontraram terreno para negociação e ação conjunta (HYPOLITO, 2019).

Ainda durante o governo Dilma Rousseff, em 2015, a primeira versão da BNCC foi elaborada em gabinetes da Secretaria de Educação Básica do MEC por uma equipe de 116 especialistas e divulgada para consulta pública em setembro do mesmo ano (BRASIL, 2015). Conforme Antunes (2019), o sistema para participação on-line no portal do MEC foi aberto em setembro de 2015, e as contribuições feitas até dezembro do mesmo ano foram disponibilizadas em fevereiro de 2016. Entretanto, o sistema para inserções de contribuições ficou aberto durante todo esse período até março de 2016, e a segunda versão, que deveria, em tese, considerar criticamente as contribuições, foi divulgada em maio de 2016. Considerando que, no período, registraram-se mais de 12 milhões de contribuições, segundo o próprio MEC (BRASIL, 2016b), restam, no mínimo questionáveis, o procedimento e os critérios para sua leitura, ponderação, rejeição ou incorporação delas ao documento. Já o formato da participação não oferecia à "comunidade em geral" a opção de contestar a própria necessidade de uma Base, assim como sobre as possibilidades de discutir concepções de Base e de currículo. A participação estava limitada a indicar em cada item do documento uma das opções: concordo fortemente, concordo, sem opinião, discordo e discordo fortemente. Aos últimos havia apenas as opções de oferecer sugestões de alteração da redação, alteração da ordem ou exclusão do item. Além da "comunidade em geral", foram solicitados pareceres de mais de 80 especialistas das diferentes áreas do conhecimento (BRASIL, 2016a).

A primeira versão da Base, ainda durante o governo Dilma Rousseff, embora preocupada com a diversidade de manifestações de humanidade, não trazia sequer uma menção à palavra "capitalismo". Assim, temas imprescindíveis para compreender a composição da sociedade contemporânea industrial, tal como "Revolução Industrial", constavam apenas nos temas importantes para o componente de física, com abordagem direcionada aos avanços tecnológicos (BRASIL, 2015). Resta evidente a pressão de grupos desejosos de construir uma narrativa apaziguadora das contradições sociais e naturalizadora do capitalismo. Fica clara, à despeito de ter sido proposta ainda durante um governo do Partido dos Trabalhadores, a influência de grupos neoliberais, especialmente das instituições que gravitavam em torno do Movimento pela Base, principal propagandista da reforma e formado por instituições privadas, algumas delas vinculadas diretamente ao setor financeiro, com e sem fins lucrativos (MOVIMENTO PELA BASE, 2017).

Após o curtíssimo intervalo entre o fechamento do sistema para contribuições e o envio dos pareceres dos "leitores críticos", o MEC divulgou para o público a segunda versão da BNCC que, supostamente, incorporaria as críticas ou, ao menos, as levaria em consideração. $\mathrm{O}$ argumento utilizado para justificar a não inserção das contribuições no texto do documento foi a de que ele "[...] deveria ser de natureza operativa, não cabendo aprofundamentos teóricos e metodológicos" (BARBOSA; SILVEIRA; SOARES, 2019, p. 81). A consulta e os pareceres, então, cumpriram a função de envernizar de diálogo um processo fechado e antidialógico. Nesse momento, muitos pesquisadores de diferentes áreas do conhecimento se manifestavam, ainda, entusiastas sobre a construção de um documento norteador, de uma Base Nacional. Alguns, inclusive, se mostraram dispostos a contribuir com o MEC na melhoria do texto com o declarado objetivo de produzir o melhor currículo possível para as crianças e os jovens brasileiros e, assim, ofereceram seu prestígio acadêmico para a elaboração das duas primeiras versões (HYPOLITO, 2019). Alguns deles, como Caimi, leitora crítica da área de Ciências Humanas, especialmente de História, da primeira versão, embora apontasse problemas e tensões entre os redatores, não escondia o otimismo com a 
Base Nacional Comum Curricular e o canto da sereia da educação normalizante...

produção da BNCC. Em artigo publicado no período entre a primeira e a segunda versão, a autora afirma:

A expectativa é que esse processo tortuoso de elaboração da Base Nacional Comum Curricular possa extrapolar os limites da guerra de narrativas [...] e instaurar uma cultura de debate público acerca da escola, do currículo escolar, da formação docente, dos materiais didáticos, da aprendizagem, da avaliação em larga escala, dentre outros temas tão relevantes nos cenários educativos e sociais. Que o debate em curso prime pelo pluralismo de ideias e se mostre aberto à construção do novo! (CAIMI, 2016, p. 91).

Após a publicação da segunda versão, os grupos de trabalho sobre a elaboração da BNCC foram dominados por atores vinculados às entidades empresariais reformadoras e aos movimentos ultraconservadores que procuram, por diversas estratégias, esvaziar o conteúdo propriamente educativo da escola, o que favoreceu o endurecimento da BNCC, a defesa de seu caráter normativo e vinculante às demais políticas do campo, a ênfase na competitividade e no gerencialismo (ANTUNES, 2019; ZANOTTO; SANDRI, 2018) e a exclusão de discussões demasiadas importantes em um país complexo como o Brasil, tais como os estudos de gênero, as relações étnico-raciais e os conflitos sociais produzidos pelo modelo de capitalismo vigente na sociedade brasileira, que caracterizam a versão final. Conforme Hypolito (2019, p. 195), "[...] a terceira versão já foi bastante conservadora e não absorveu muitos dos preceitos liberais para uma educação pública". Aqui, aos interesses dos setores neoliberais, foram acrescidas bandeiras neoconservadoras.

O período entre as publicações da segunda e da terceira versões da BNCC, entre maio de 2016 e abril de 2017, foi marcado pela disputa pelo controle da elaboração do texto, assim como pela substituição de especialistas envolvidos desde o princípio da elaboração do documento e o subsequente loteamento das cadeiras do CNE entre apoiadores das políticas educacionais do governo Temer vinculados ao Movimento pela Base (PORTAL EBC, 2016). Nesse ínterim, realizaram-se seminários estaduais em todos os Estados, constituiu-se o Comitê Gestor da BNCC (BRASIL, 2016a) e o Governo, via Medida Provisória, depois transformada em Lei, "reformou” o Ensino Médio (BRASIL, 2017a). Indiferente a tudo isso, o MEC elaborou, em gabinetes (BARBOSA; SILVEIRA; SOARES, 2019) e sob forte influência de grupos neoconservadores e populistas-autoritários (HYPOLITO, 2019), a terceira versão da BNCC, apresentando-a em abril de 2017, sem incluir o Ensino Médio. A partir da divulgação, o MEC organizou audiências públicas, uma em cada região, com caráter consultivo. Hypolito (2019) destaca que essa versão, que depois tornar-se-ia definitiva com sua aprovação no CNE em 15 de dezembro de 2017 e sua publicação, como Resolução CNE/CP n 2 2, de 22 de dezembro de 2017 (BRASIL, 2017b), sete dias depois, apresenta conteúdos retrógrados e conservadores mesmo para as demandas neoliberais que, até a segunda versão, eram hegemônicas: mesmo meras menções aos estudos de gênero foram excluídas. Em maio de 2018, o MEC apresentou ao CNE o texto da BNCC para o Ensino Médio e, seguindo o mesmo expediente, homologou-a e publicou-a em 14 de dezembro de 2018 (BRASIL, 2018b).

Não apenas entre uma etapa e outra da formulação da BNCC o processo foi marcado pela pressa, mas também o período todo, entre 2015 e 2018 foi demasiado enxuto para que um documento com esse teor, com tantas instituições, entidades, associações e indivíduos envolvidos, pudesse receber o devido tratamento, a não ser pela via da imposição, do desrespeito ao processo democrático por meio de simulacros de participação popular e de especialistas. Essas manipulações recebem um verniz de democracia ao incluir quantitativamente e excluir qualitativamente: incluem os expressivos números e excluem as contribuições. Nesse espírito, ainda em 2018, antes da homologação da versão que incluía o Ensino Médio, o MEC criou o Programa de Implementação da BNCC (ProBNCC) com o objetivo de auxiliar e acompanhar a implementação da base nos Estados e municípios (BARBOSA; SILVEIRA; SOARES, 2019). Com apoio de entidades como a 
União Nacional de Dirigentes Municipais de Educação e a União Nacional dos Conselhos Municipais de Educação, além da vinculação de recursos para essas esferas sob a condição de revisão dos currículos com alinhamento à BNCC (BRASIL, 2018a), consolidou-se a transição do que era uma Base Nacional Comum (um documento orientador de referência) para uma Base Nacional Comum Curricular: uma prescrição propensa à homogeneização de conteúdos, à padronização da avaliação e à normalização, rotinização e mecanização das relações entre os sujeitos envolvidos no processo educativo.

\section{A BNCC como Educação Normalizante}

A inclusão de "curricular" à Base Nacional Comum não é mero casuísmo, outrossim explicita a intenção de fazer da BNCC mais do que um documento orientador, como eram os PCN e as DCN. A BNCC, normativa e articulada aos processos de avaliação de larga escala, prescreve o currículo, as formas de aferição do currículo ensinado e aprendido, assim como responsabiliza as escolas e, especialmente, os professores pelo fracasso ou sucesso nos processos avaliativos padronizados. A ênfase na padronização do que é ensinado e aprendido nas escolas e na prescrição do currículo pelo que é avaliado por exames sistêmicos se manifesta quando os elaboradores justificam a organização curricular por competências, pois elas são, também, elementos referenciais "[...] nas avaliações internacionais da Organização para a Cooperação e Desenvolvimento Econômico (OCDE) que coordena o Programa Internacional de Avaliação de Alunos (Pisa, na sigla em inglês)" (BRASIL, 2018a, p. 13). O discurso de que a educação precisa atender a demandas específicas da sociedade contemporânea e estar concentrada em dotar o indivíduo de habilidades e de competências que o tornariam apto para a vida e para o trabalho no século 21 constituem facetas refinadas do processo de normalização e rotinização das relações. O mundo, nessa concepção, já está posto: a sociedade funciona "desta maneira" e estabelece de antemão o que deve se tornar cada novo ser humano. A preocupação em adaptar a criança e o jovem tem como objetivo subjacente a manutenção do mundo como ele é. O que se está preservando não é o mundo enquanto lugar da pluralidade do que é humano, nem mesmo o que é especificamente humano, mas tão só o status quo. Ao contrário, com Arendt (2016, 2017), afirma-se que o que "faz" um ser humano ser diferente dos membros das outras espécies é a capacidade de vir a tornar-se algo que ainda não foi pensado a partir de sua ação no mundo plural. Uma efetiva Educação precisa provocar o indivíduo e manter sempre aberta a possibilidade de algo novo, imprevisto. Já a educação sustentada em habilidades e competências é transvestida em tecnologia (BIESTA, 2017) e está, quando muito, preocupada com a qualificação para o mundo competitivo e com um tipo de socialização limitada à adaptação, sem espaço para a subjetivação.

A essas formas de educação que socializa pela dessubjetivação e que apela para a evidência da naturalidade das relações que não são naturais (como são todas as relações entre seres humanos) se denomina, seguindo Gur-Ze'ev (2005a, 2005b, 2010a, 2010b), Educação Normalizante. Em Gur-Ze'ev (2005b):

A educação normalizante deve integrar um aparato conceitual específico em um conjunto específico de valores. Conceitos como "igualdade" e valores como "liberdade" não são naturais, autênticos ou originais - são fabricados. Eles são produzidos em um momento histórico específico em um material concreto e um ambiente simbólico, para os quais eles servem e representam. $O$ véu do Ser é tecido a cada novo momento. [...]. A evidência, não apenas nos horizontes da razão crítica, da coexistência morna e do distanciamento da natureza, encobre a possibilidade de enfrentar a violência, que estabelece conceitos específicos como relevantes, verdadeiros ou possíveis e outros como não. [...]. A educação normalizante só é possível porque resultado de seu enorme sucesso criativo. (GUR-ZE'EV, 2005b, p. 165, tradução nossa). 
A terceira e definitiva versão da BNCC sustenta, como objetivo de uma "boa educação", a aquisição de um conjunto de competências e de habilidades. Conforme Neitzel e Schwengber (2019, p. 213), "[...] competência designa aptidão para realizar determinada operação previsível, de agir segundo uma rotina protocolar. Isto é, ter competência é agir sobre algo a partir de um conhecimento e o preparo para tal". De forma similar, "habilidade" implica executar tarefas a partir da mobilização de saberes, de recursos, de objetos, de instrumentos etc. A BNCC está organizada por meio de Competências Gerais, Competências Específicas das Áreas, Competências Específicas de Componentes, e, nesses, Unidades Temáticas, Objeto de Conhecimento e Habilidades. Em tese, o domínio gradual das habilidades implica aquisição das Competências Gerais. Ao todo são 10 competências gerais para a Educação Básica. Resta difícil estabelecer qualquer oposição às Competências Gerais declaradas na BNCC para a Educação Básica. O texto sugere até mesmo que bandeiras caras aos movimentos progressistas do campo educacional foram encampadas. Por exemplo, as Competências Gerais de número 6 e 9 apresentam:

Valorizar a diversidade de saberes e vivências culturais e apropriar-se de conhecimentos
e experiências que lhe possibilitem entender as relações próprias do mundo do trabalho
e fazer escolhas alinhadas ao exercício da cidadania e ao seu projeto de vida, com
liberdade, autonomia, consciência crítica e responsabilidade.
[...]
Exercitar a empatia, o diálogo, a resolução de conflitos e a cooperação, fazendo-se
respeitar e promovendo o respeito ao outro e aos direitos humanos, com acolhimento e
valorização da diversidade de indivíduos e de grupos sociais, seus saberes, identidades,
culturas e potencialidades, sem preconceitos de qualquer natureza. (BRASIL, 2017b, p.
9-10).

É justamente essa criatividade para se reinventar, para absorver elementos da crítica, que, no caso do processo de elaboração da BNCC, teve espaço simbólico nas mais de 12 milhões de contribuições e nos pareceres dos leitores críticos, e se reapresentar como o moderno, como o inovador, o que possibilita o sequestro sempiterno das possibilidades de uma educação efetiva que favoreça a humanização e que se esforce para superar as injustiças e dignificar as relações sempre tensas e complexas entre seres humanos. Essa criatividade também oferece uma defesa imunológica ao sistema de valores dominantes, contra as potenciais críticas que denunciam a sua violência e falta de sentido, ou melhor, sua recusa em considerar qualquer outro sentido que não o sentido irresistível (porque não se pode oferecer resistência) do próprio mercado e da Tradição, materializados na BNCC.

A rotinização das relações fica evidente na concepção do processo educativo implícito na BNCC, se considerarmos que, efetivamente, atingir as Competências Gerais declaradas seja o objetivo de tal empreendimento. Os elaboradores do documento parecem crer que desenvolvendo as Competências Específicas de cada componente atingir-se-ão as Competências Específicas das Áreas e que, a junção dessas, por sua vez, concretiza a aquisição das Competências Gerais. Tudo isso partindo dos "objetos de Conhecimento e Habilidades". Fica clara a concepção neoliberal de fundo, para a qual a educação é uma tecnologia para adquirir coisas, um meio para ter algo que não se tinha antes e em que não há nenhum risco de se obter algo diferente daquilo que já estava previsto e formalmente acordado entre as partes (BIESTA, 2017). Como se pela mobilização de conhecimentos científicos fosse possível atingir uma atitude ética em um mundo plural e democrático; em outras palavras, como se a democracia e a ética fossem o produto de um conjunto de ações possíveis de programar. A escola converte-se em um balcão de loja e a educação em uma mercadoria disponível em uma das prateleiras (CAMPBELL; SHERINGTON, 2006; BALL, 2012; BIESTA, 2017). A vinculação das Competências Gerais com os critérios de avaliação dos exames padronizados denuncia que a competência mais importante para os elaboradores da BNCC está omissa, pelo menos textualmente: a capacidade de competir, de obter bons resultados. A educação torna-se, então, um serviço prestado para melhorar a empregabilidade, uma tecnologia aplicável a 
um fim externo. A Competência Geral de número 10, por exemplo, exalta a capacidade de adaptação em um mercado cada vez mais competitivo e fechado, com baixas expectativas de emprego: "Agir pessoal e coletivamente com autonomia, responsabilidade, flexibilidade, resiliência e determinação, tomando decisões com base em princípios éticos, democráticos, inclusivos, sustentáveis e solidários" (BRASIL, 2018a, p. 10). Aqui se verifica o que Guer-Ze'ev (2005b) salienta: um ludibriamento por meio do uso de valores inquestionáveis, mas que perderam seu conteúdo objetivo. A ênfase dessa competência, se lembrarmos da relação direta estabelecida com os sistemas de avaliação padronizados, não está em "responsabilidade", "ética", "democracia", "inclusão" ou "solidariedade", mas em "flexibilidade, resiliência e determinação"; de outro modo, em competição e adaptação ao mundo como ele é. As bem-intencionadas competências configuram-se como um canto de sereia. No fundo, a competência mais valorizada pela BNCC é a competência de competir em um mercado cada vez mais exigente e excludente.

A preocupação explícita com os indicadores de qualidade contribui significativamente na subversão da educação em uma mera tecnologia. Pressionados por gestores e pela opinião pública, os professores podem direcionar seus esforços não para ajudar seus alunos a viver de forma adulta e responsável em um mundo plural e complexo, mas em melhorar os indicadores. Como não é possível mensurar uma atitude ética, mas é possível um dado, o perigo é que a escola deixe de se preocupar com ética e se converta em uma fornecedora de informações mensuráveis, perdendo, assim, sua função educativa (BIESTA, 2009, 2017, 2018). Isso não é um fenômeno exclusivamente brasileiro, há, desde os anos de 1980, um grande esforço global de estabelecer métricas padronizadas de aferimento da qualidade da educação (BALL, 2012; AVELAR; BALL, 2017, PONGRATZ, 2006).

No caso brasileiro, as relações mercadológicas de competição são tratadas como naturais e as competências incidem em competências para melhor se adaptar ao mundo naturalizado. $\mathrm{O}$ mercado possui demandas e espera que as novas gerações, os que hoje são crianças e jovens, estejam em condições de atendê-las. Daí porque o palatável argumento de que é um direito das crianças e dos jovens pobres o acesso a mesma educação que as crianças e os jovens de classes sociais elevadas (BRASIL, 2018a) se mostra um engodo, já que não se coloca em questão a organização dessa sociedade que cria ricos e pobres. Às crianças e aos jovens pobres resta como alternativa adquirir competências para circular em um mundo competitivo que inclui uns excluindo outros, já que a liberdade para criar um mundo novo não é oportunizada. Mesmo as possíveis oportunidades de melhoria de vida atreladas ao sucesso educacional são restritas a opções já estabelecidas. Se não há espaço para o novo, não há espaço para se tornar um ser humano (ARENDT, 2016, 2017; BIESTA, 2017, 2018; GUR-ZE’EV, 2005b).

A educação normalizante, criativa e capaz de absorver as críticas de modo a torná-las parte de si mesma, pode, assim, mobilizar toda uma crítica aos seus jogos de poder e inseri-la no próprio jogo de poder, na própria máquina do prazer que atende aos desejos e aos interesses imediatos, que não são naturais, mas construídos histórico-socialmente, dos sujeitos do empreendimento educacional (GUR-ZE'EV, 2005b, 2002). A BNCC procura estabelecer a norma, padronizar a educação e normalizar as relações, isso é assumido pelo próprio documento em seu caráter normativo e vinculante (BRASIL, 2018a). Isso, por si só, já autorizaria falar em educação normalizante. Entretanto, o conceito de Gur-Ze'ev interessa aqui porque não apenas a BNCC possui caráter normativo objetivo, assumido explicitamente, mas também subjetivo, porque se apresenta como caminho sem volta, com único caminho, como "a solução" para os problemas da educação brasileira. Desse modo, a BNCC apresenta-se como "a Verdade", assim como apresenta como "a Verdade" o currículo que sustenta. Não permite espaço para a criatividade, para a construção de algo novo, ainda impensado. Não permite espaço para o encontro entre o que não 
está na norma. Não permite, portanto, uma efetiva educação, que é sempre incerta e de difícil (talvez impossível) aferição por meio de testes padronizados (BIESTA, 2017; BALL, 2012).

Conforme Gur-Ze’ev (2005b, p. 166), a “nova” subjetividade (desumanizada) é elaborada de uma maneira que oculta do sujeito que ela não é nada mais do que uma manifestação, dentre as muitas possíveis, da lógica do sistema dentro do qual ela é produzida, nutrida, controlada e, sobretudo, roubada de sua outridade, de seu potencial para se tornar outra, para além daquilo que ela é direcionada para ser. O mesmo indivíduo, aquele que é a maior vítima, é também o mais entusiasmado apologista de um sistema que o impede de ser algo além do que lhe é permitido ser. Ao estabelecer o não-Eu como um eu, a partir da (auto)evidência e do consenso daquilo que "sou Eu" e ao estabelecer os critérios de avaliação dos valores (dos válidos e dos inválidos), a educação normalizante, por meio de uma violência castradora, dificulta a abertura para a outridade do outro e, também, para a outridade do Eu. Conforme Gur-Ze'ev (2005b):

\begin{abstract}
A educação normalizante é responsável não apenas por constituir o “sujeito”. Realiza-se também ao introduzir no sujeito certos corpos de conhecimento e representar os outros como irrelevantes e ilegítimos. Outros ainda são perdidos, destruídos ou engolidos pelo novo sistema. Também expele certos conjuntos de valores "perigosos"/“estrangeiros", torna outros esquecidos, irrelevantes ou ilegítimos em um processo que, ao mesmo tempo, impõe um certo aparato de avaliação que é imanente à ordem hegemônica. A estabilidade do reino hegemônico da autoevidência e da identificação com o sistema é muito dependente desse aparato de avaliação. (GUR-ZE’EV, 2005b, p. 165, tradução nossa).
\end{abstract}

O indivíduo dessubjetivado é mero produto do meio, uma partícula da coletividade, do grupo, um espelho de seu tempo incapaz de oferecer algo novo. O (não-)ser torna-se um objeto de manipulação e reproduz, na condição de vítima entusiasta, a violência contra si mesmo e contra tudo que for outro. Conforme aponta Gur-Ze'ev (2005b, p. 162), essa subjetividade fabricada opera como uma camuflagem eficiente pelas quais o sistema esconde sua "[...] violenta reprodução da ordem hegemônica das coisas e do reino governado pela autoevidência". A educação normalizante reproduz o presente como única possibilidade viável para o sujeito e, assim, sequestra o futuro por sua negação à novidade, por sua recusa em desafiar o presente, em desafiar o que está posto como norma. Pelo ludibriamento em seu discurso, a BNCC é proteica, e, com Proteu, evita a todo custo mostrar-se como é. Entretanto, como Proteu se revela àqueles que o encaram corajosamente e, nesse momento, se denuncia como Jano: com duas faces distintas e integradas em uma mesma cabeça: uma neoliberal e outra neoconservadora. Sobre as faces da BNCC se dedicam as duas partes seguintes.

\title{
A face neoliberal da BNCC
}

O neoliberalismo, diferentemente das outras metanarrativas do século 20, não se apresenta como uma utopia a ser realizada no futuro, mas como a própria Verdade, como o caminho sem volta. Isso, é claro, não significa que não seja uma utopia, uma promessa (KAŠČÁK; PUPALA, 2011), mas tão só que se fortaleça porque se recusa a se assumir como tal. É por essa razão que o neoliberalismo é, hoje, o que Foucault (2008) chamou de "episteme", uma maneira de pensar que constitui a base da realidade social. Essa "nova episteme" procura convencer que qualquer oposição a ele é um desperdício de tempo, uma tentativa fraca e irrelevante para resolver os processos econômicos e sócio-políticos de livre mercado. Em Foucault (2008), o (neo)liberalismo é mais do que uma forma de organização dos mercados. É, sobretudo, um método de pensamento que se arvora como um estilo geral de pensamento, análise e imaginação; em outras palavras, uma utopia que procura se apresentar como "a Verdade natural", a norma, e, como tal, normaliza os indivíduos. A educação é um dos principais setores de interesse do processo de normalização neoliberal. 
Pela cartilha neoliberal, o Estado deve abrir todas as atividades para a livre iniciativa, desregulamentar por meio de legislação o uso dos recursos naturais e as relações de trabalho, conceder a, e até mesmo criar a demanda para, construção de infraestrutura à iniciativa privada (MCMURTRY, 1999; KARLSSON, 2002; OLSO; PETERS, 2005; MCLAREN; FARAHMANDPUR, 2001). Assim, enquanto no liberalismo clássico se entende que o Estado deve ficar fora das relações de mercado, garantindo a segurança para a livre iniciativa, no neoliberalismo o Estado torna-se um servo do setor privado e promove a todo o custo a expansão de suas atividades (GUILHERME; PICOLI, 2019). Isso ajuda a explicar o aparente paradoxo da criação de uma norma legal, uma intervenção do Estado portanto, em um setor tão importante como a educação a despeito da defesa da desregulamentação de todas as atividades sustentada pelos apologistas do neoliberalismo: a BNCC, uma norma, atende aos interesses de indivíduos, grupos e instituições ligadas ao mercado financeiro e desejosas de indivíduos flexíveis às adversas condições do mercado e conformados com a "natureza imutável" das mais perversas condições. Muitas dessas instituições foram, desde o início do processo de composição da BNCC, suas principais propagandistas: o Movimento pela Base é formado por instituições vinculadas ao setor financeiro, das quais se destacam a Fundação Lemann, a Fundação Roberto Marinho, o Instituto Ayrton Senna, o Instituto Unibanco e o Itaú BBA (MOVIMENTO PELA BASE, 2017).

No Brasil, a racionalidade neoliberal na educação não é um fenômeno recente; ao contrário, está no cerne da organização escolar desde a LDB, de 1996, ampliada pelo PNE de 2001 e pela criação do Sistema Nacional de Avaliação da Educação Básica (SAEB), também de 2001 (ZANOTTO; SANDRI, 2018). Contudo, a BNCC constitui-se em uma política curricular que visa intensificar o gerencialismo na educação por meio do aprofundamento do controle da gestão escolar, além do trabalho dos professores e do processo de formação do conhecimento dos estudantes (ZANOTTO; SANDRI, 2018). Uma das formas de controle que têm se mostrado mais eficazes por, indiscutivelmente, apresentar resultados são os testes, especialmente os padronizados. Para Mancebo (2004), os exames e os testes, dos mais variados tipos, foram ocupando todos os espaços em que a lógica neoliberal se instaurou, e fizeram isso por intermédio de um discurso sedutor e, dentro de estreitos quadros, eficaz, já que efetivamente as formas de mensuração medem alguma coisa. A questão que não se apresenta é se o que eles medem é o que de fato importa, especialmente em Educação (BIESTA, 2017; BALL, 2012). De todo modo, tornaram-se a forma central do controle (e do autocontrole) da racionalidade gerencial neoliberal.

De acordo com a LDB (BRASIL, 1996), em seu Art. $9^{\circ}$, é prerrogativa da União a avaliação da qualidade da educação nacional e, a partir disso, a definição de prioridades no setor. Por meio desse dispositivo, atua utilizando como ferramenta testes padronizados e, agora, a definição de um currículo nacional normativo. Age como servo dos interesses do mercado. Na lógica do gerencialismo, o Estado cumpre a tarefa de Estado-Avaliador. Importante esclarecer que não se quer afirmar que os testes não importam, que não oferecem alguma base material para pensar a educação. O que se quer afirmar é que, seguindo Freitas (2013), na lógica neoliberal, os limites dos testes, como ferramenta de aferimento, foram ignorados e eles assumiram a função de controle ideológico, nem tanto pelo que incluem em seus procedimentos, mas, sobretudo, pelo que excluem, ou seja, o que os testes não podem mensurar. Exercem, assim, o controle sobre os indivíduos envolvidos no empreendimento educativo. Nesse cenário, como afirma Ball (2012), os professores não passam de técnicos que aplicam protocolos mensuráveis, ou, ainda pior, meros bonecos de ventríloquo por cujas bocas emergem ideias alheias ao que interessa em educação. A centralidade que os exames assumiram na racionalidade neoliberal compreende uma terrível distorção pedagógica (SAVIANI, 2016). Em termos simples, os testes não atuam no sentido de ajudar a pensar os rumos da educação, mas os rumos da educação é que são pensados para melhorar os índices de desempenho nos testes. 
Os testes, especialmente os padronizados de larga escala, cumprem o papel de definidores do currículo e de impulsionadores de valores (competências) caros ao mercado neoliberal: competição, ranqueamento, (auto)responsabilização (ZANOTTO; SANDRI, 2018). Os ranqueamentos, embora possam partir de uma perspectiva bem intencionada de elevação dos padrões acadêmicos, incorrem no risco de que as justificativas das ações educativas sejam simplesmente melhorar seus indicadores nos rankings (BIESTA, 2017; BALL, 2012). As instituições de ensino tendem a tornar-se orientadas para as demandas do mercado e a educação é corrompida em mera commodity (PONGRATZ, 2006; GUILHERME; PICOLI, 2019). Connell (2009, p. 109) aponta que isso leva ao desenvolvimento de um "tribunal permanente de qualidade" que estabelece e intensifica a concorrência entre professores, alunos e instituições. De acordo com a perspectiva de mercado, as instituições tornam-se meros provedores de serviços e os estudantes tornam-se meros consumidores, clientes (CAMPBELL; SHERINGTON, 2006).

A Educação neoliberal, como commodity, exige que todos os esforços, desde as práticas pedagógicas até as políticas de organização e financiamento, devem estar direcionados ao desenvolvimento do capital humano normalizado. Não é incomum que, para conseguir isso, sejam incorporados elementos críticos destituídos de seu caráter efetivamente crítico (GUR-ZE'EV, 2005a; CARTER; DEDIWALAGE, 2010), como é o caso das alegadas Competências Gerais da BNCC. De acordo com Kašćák e Pupala (2011), o neoliberalismo é muito inteligente ao incorporar perspectivas, originalmente pensadas para lhe fazer resistência e mobilizá-las para o desenvolvimento do capital humano e padronização dos indivíduos, características que Gur-Ze'ev atribui às diversas formas de Educação Normalizante. Como Connell (2013) aponta, a base interna de valores e conhecimento técnico promove um sentimento de satisfação que dificulta qualquer crítica ao sistema. Isso significa que o indivíduo é, ao mesmo tempo, uma vítima e um entusiasta desse tipo de educação, porque, em teoria, qualquer pessoa pode ter sucesso e isso só depende do desempenho e dos esforços do indivíduo. Há uma combinação complexa de controle externo (do mercado) e autocontrole (do indivíduo). Os interesses do indivíduo em um mundo de livre mercado compreendem estratégias para tornar-se competitivo nesse mundo (OLSSEN; PETERS, 2005; PETERS, 2001). O outro só aparece como aquele contra quem é preciso competir.

Como uma episteme, uma maneira de pensar, o neoliberalismo precisa controlar o discurso educacional para incutir valores em crianças e jovens, particularmente com respeito ao sucesso individual (autodeterminação) e liberdade de escolha nas trocas entre o indivíduo e os outros. Pongratz (2006) e McLaren e Farahmandpur (2001) afirmam que, na lógica desse pensamento, o fracasso e a pobreza são tomados como responsabilidades de indivíduos que não conseguem sucesso porque são demasiadamente preguiçosos, ignorantes ou não procuraram tornar-se mais qualificados para o mercado de trabalho em transformação. De acordo com Pongratz (2006), com um discurso fragmentário e reformas parciais, o neoliberalismo estabeleceu um controle centralizado da educação com uma nova metanarrativa que é uma nova forma de governança do setor escolar. A estratégia de "soft power" da concorrência, das disputas de classificação (ranqueamento) por parte do Estado e das instituições supranacionais, fornece uma forma de controle baseado em autocontrole do indivíduo que é aliado à ideia de responsabilidade pessoal pelo próprio sucesso ou fracasso (PONGRATZ, 2006).

Com uma aparência de liberdade e de democracia, a educação neoliberal é uma manifestação mais profunda da educação normalizadora. Gur-Ze'ev (2005b, p. 332) afirma que "[...] a educação normalizadora é baseada em um consenso inquestionável e está comprometida com a segurança de suas próprias evidências". Normalizar a educação não significa apenas introduzir um conjunto de valores, mas também estabelecer e naturalizar o que se considera relevante e válido, e, consequentemente, o que é irrelevante e não válido. Assim, os valores que corroboram a Verdade do neoliberalismo são tratados como "verdadeiros" e, portanto, válidos; em 
contrapartida, os valores que questionam o sistema são combatidos como "ideologia" (GURZE'EV, 2007, p. 164). Assim, o diagnóstico de Zanotto e Sandri (2018) é preciso:

[...] as políticas de avaliação do desempenho dos estudantes medidas por instrumentos
de avaliação em larga escala, dizem atestar, através dos resultados aferidos, a qualidade
da educação brasileira. No entanto, estes dados, estão servindo muito mais para classificar
e fazer comparações entre instituições, do que que para agregar esforços na superação
das fragilidades do sistema, fragilidades estas que também são responsáveis pelos índices
de qualidade. Assim, pela avaliação, acaba por se direcionar os rumos que as práticas
escolares vêm tomando no âmbito do ensino brasileiro. (ZANOTTO; SANDRI, 2018,
p. 133).

Tudo é um cálculo contábil e produto em prateleiras. Professores e alunos são números em uma planilha, são indicadores, desumanizados. A educação é uma commodity. Aos interesses neoliberais, na BNCC, somaram-se interesses neoconservadores, a outra face da BNCC.

\section{A face neoconservadora da BNCC}

Além da influência neoliberal, a composição da BNCC também foi marcada pela forte articulação de outro grupo político com grande interesse no campo educacional: os neoconservadores. Esse grupo, que dispõe de algumas bandeiras que se aproximam demasiadamente das pautas neoliberais (como a meritocracia e a queixa da interferência do Estado na definição das diretrizes educacionais), possui especificidades marcadas pelo reacionarismo e não está afeito à submissão de suas reivindicações morais nem mesmo em nome dos "interesses do mercado" (LILA, 2018, p 12). É claro que esse segmento sempre esteve presente na sociedade brasileira, pressionando os representantes públicos com interdições no campo da saúde pública e dos direitos humanos, como, por exemplo, nos debates sobre a legalização do aborto, do consumo de drogas e do casamento homoafetivo (CECHETTI; TEDESCO, 2020). Entretanto, desde meados da primeira década do século 21, verificou-se, no Brasil, embora não só (APPLE, 1993; BAUMAN, 2017; LÖWY, 2015), uma maior articulação desse grupo na mobilização de suas pautas morais. É pertinente afirmar que as redes sociais favoreceram o "encontro on-line" desses indivíduos que passaram a se engajar na defesa de seus valores, reproduzindo e difundindo concepções de mundo que, antes do advento dessas ferramentas, não encontravam a mesma ressonância (GUILHERME; PICOLI, 2017). As manifestações em redes sociais, fóruns temáticos e em portais de notícias em situações específicas aglutinaram e fortaleceram essas redes neoconservadoras. No campo específico da educação, a polêmica em torno da Política Nacional de Combate à Homofobia (Kit Gay) aglutinou muitos apoiadores de pautas morais reacionárias (ROMANCINI, 2018).

Além disso, é interessante destacar o papel, a cada ano maior, desempenhado pelas instituições religiosas neopentecostais e pela ala conservadora do catolicismo. O primeiro grupo, especialmente, tem, a cada renovação do corpo legislativo dos municípios, Estados e da União, aumentado seus quadros e composto uma bancada suprapartidária com um eleitorado cativo (CECHETTI; TEDESCO, 2010). Esses representantes, então, adquirem o direito de participar de diversas comissões parlamentares que analisam, reformam ou rejeitam projetos de leis, além de submeter projetos de leis nos mais diversos campos. A atuação desses representantes, em temas relacionados à educação, foi significativa no processo de aprovação do texto do PNE, que só foi aprovado e publicado com quatro anos de atraso porque os membros dessa bancada exigiam a retirada da obrigatoriedade de temas relacionados aos Estudos de Gênero no currículo da Educação Básica (GUILHERME; PICOLI, 2018). Assim, questões como direitos das mulheres, violência doméstica, representatividade de gênero, combate à homofobia e outras formas de 
preconceito de gênero, orientação sexual etc., passaram a figurar como secundários na formação dos jovens brasileiros.

Um dos principais movimentos aglutinadores dos neoconservadores brasileiros no campo educacional é o Movimento Escola sem Partido que, desde 2004, defende que a educação das crianças é exclusividade da família, cabendo à escola apenas a transmissão "neutra" de conteúdos (GUILHERME; PICOLI, 2018). Conforme Penna (2016, p. 52): "Independentemente de quais sejam os valores morais transmitidos pelos pais aos filhos, eles não poderiam ser contraditos na escola". Como fundo, manifesta-se a defesa de que a educação é uma atribuição exclusiva da família, da esfera privada. A defesa neoconservadora dos direitos da família em educar suas crianças e seus jovens sem a intromissão do Estado, também fez surgir um movimento que exige a regulamentação da Educação Domiciliar (sem escola) e que tem proposto isso pela via do Legislativo Federal. Além de vários projetos de diversos autores na Câmara dos Deputados e no Senado Federal (VASCONCELOS; BOTO, 2020; CASANOVA; FERREIRA, 2020; PICOLI, 2020), a pressão desse movimento levou o atual Poder Executivo, fortemente conservador nas questões de comportamento, a apresentar à Câmara um projeto de lei de sua própria lavra. $\mathrm{Na}$ proposição, manifesta-se a preocupação em esclarecer que a educação domiciliar não tem relação com o domicílio, outrossim que se caracteriza como um "[...] regime de ensino de crianças e adolescentes, dirigido pelos próprios pais ou pelos responsáveis legais” (BRASIL, 2019a, p. 1). Na proposição, o Estado assume o papel de Estado-Avaliador, limitando sua atuação a averiguar o desempenho por meio de um exame anual (PICOLI, 2020), em um claro encontro entre o neoconservadorismo e o neoliberalismo. Outras ações no campo demonstram a força desse grupo no Brasil contemporâneo, como, por exemplo, o Decreto $\mathrm{N}^{\circ} 10.004$, de 5 de setembro de 2019 (BRASIL, 2019b), que cria o programa de militarização das escolas públicas de Educação Básica (MENDONÇA, 2019). Além disso, os grupos neoconservadores costumam atacar os livros didáticos afirmando que eles operam uma lavagem cerebral ideológica nas crianças e adolescentes, além de promover a obscenidade e a libertinagem sexual (PENNA, 2015).

Um elemento que caracteriza o neoconservadorismo brasileiro é a ficção reacionária da “perda do mundo" para o inimigo entre nós (GUILHERME; PICOLI, 2018, p. 13), presente nas entrelinhas das justificativas dos PLs do Escola sem Partido e do Homeschooling, do Decreto da militarização e no ataque às produções científicas presentes nos livros didáticos. O mito da perda do mundo foi exaustivamente analisado por autores que se debruçaram sobre as experiências totalitárias do século 20 (ARENDT, 1973). No caso brasileiro, o "inimigo entre nós" e que "conspira contra nós" que serve como pano de fundo para a narrativa neoconservadora são os grupos que têm conquistado direitos e visibilidade nas últimas décadas, especialmente os LGBTs. Afirmam que está em curso no mundo e, como corolário, no Brasil, um projeto de implantação de uma "ditadura gay de orientação marxista". No mês de março de 2017, um deputado federal apoiador do Projeto Escola sem partido, em entrevista radiofônica, expôs suas preocupações com a conspiração global a partir do que afirmou ser uma análise profunda de uma personagem infantil. Conforme o deputado:

\footnotetext{
Em relação a essa situação do Mickey e da Disney, a gente vê que em todas as suas atuações, eles fazem apologia ao homossexualismo. Inclusive o Mickey, se você fizer um estudo profundo como eu já fiz, ele é homossexual. As pessoas estão enganadas com essa mensagem subliminar que a Disney está passando para a sociedade, principalmente às nossas crianças [...]. (O ESTADO DE SÃO PAULO, 2017, n.p.).
}

Em razão da repercussão da entrevista, o deputado publicou uma nota de esclarecimento para explicar pontos que, em seu entendimento, não foram explorados a contento. $\mathrm{Na}$ nota, divulgada em suas redes sociais, afirmou que "[...] está claro que aderiram a agenda da militância marxista mundial. Isso faz parte de uma engenharia social que busca acabar com os valores cristãos" 
(GALLI, 2017, n.p.). O mito da "perda do mundo" e da "implantação da ditadura gay-comunista" embalou muito dos debates nas comissões que aprovaram o texto do PNE. Á época, outro deputado federal, então presidente da Comissão de Direitos Humanos e Minorias da Câmara dos Deputados, declarou à jornalistas que "[...] o movimento LGBT se levanta com uma doutrinação nacional. Eles se levantam nesse nosso país como uma ditadura, uma ditadura gay" (GOSPELMAIS, 2013, n.p.). Outro deputado federal, nesse caso durante um debate sobre o PNE, afirmou não ver "[...] por que razão um movimento quer introduzir no PNE a ideologia de gênero. A ideologia de gênero é marxista, é a mesma que se espalhou pela Europa e, no futuro, vão perceber que estão trabalhando contra si próprios" (GGN, 2014, n.p.).

É o absurdo dessa ideia o que a torna perigosa. Ela estabelece uma constante tensão entre um "nós" e um "outro". Arendt (1973, p. 333) lembra que, a despeito do absurdo de uma ideia, a intensidade e a coerência da propaganda produzem a adesão massiva: desconsideram-se todos os fatos que causam problemas à coerência da narrativa e se amplificam os que a sustentam. No limite, manipulam-se os fatos, como na polêmica do Kit Gay (ROMANCINI, 2018). O objetivo da propaganda é reduzir todo o debate ao patamar de guerra de opiniões, em que todas têm o mesmo valor. Conforme Arendt (1973), as perspectivas fundadas em bases factuais são convertidas em mera opinião e, portanto, passíveis de contestação por qualquer outra opinião, mesmo que não fundamentada. A negação da pluralidade, do "outro", a composição de uma realidade fictícia legitimadora de um conjunto de ações que vislumbram a criação de um mundo homogêneo são manifestações radicais de uma educação que normaliza indivíduos, ou seja, os impede de ser algo diferente do esperado. Ao negar o plural, o neoconservadorismo reacionário brasileiro mobiliza valores totalitários e busca instaurar uma realidade fictícia ancorada na negação e na alteração dos fatos. Para manter a unidade, o movimento precisa manipular a história com vistas a reduzir a complexidade e a pluralidade do mundo (ARENDT, 1973). Precisa, assim, omitir a pluralidade do mundo pela normalização/naturalização das relações.

Arendt (1973) salienta os perigos da negação da pluralidade: começa pela eliminação da política (do debate), sucedida pela eliminação política propriamente dita (perda de direitos) e pela eliminação física. O banimento do "inimigo" dá-se em dois momentos: o primeiro é teórico; e o segundo, físico. A BNCC é o teórico. Esses grupos neoconservadores ocuparam e praticamente dominaram as comissões que discutiram a BNCC entre a segunda e a terceira versão (HYPOLITO, 2019) e é por isso, na aliança entre neoliberalismo e neoconservadorismo, que, além do reforço da ideia da avaliação padronizada e da competição meritocrática, não se verifica na BNCC preocupação significativa com as diversas formas de violência de gênero e com a pluralidade de manifestações de humanidade. A última versão da BNCC faz 499 menções a "gênero"; entretanto, todas elas se referem a gêneros textuais (orais, poéticos, musicais, da vida cotidiana etc.). Nas 600 páginas do documento, há tão só três menções, dentre as habilidades específicas de diferentes áreas, a esses temas que tão marcadamente caracterizam a sociedade brasileira. Para os componentes de Ciências do $8^{\circ}$ ano, Geografia do $7^{\circ}$ ano e História do $9^{\circ}$ ano, encontram-se, respectivamente: "Selecionar argumentos que evidenciem as múltiplas dimensões da sexualidade humana (biológica, sociocultural, afetiva e ética)" (BRASIL, 2018a, p. 349); "Analisar a distribuição territorial da população brasileira, considerando a diversidade étnico-cultural (indígena, africana, europeia e asiática), assim como aspectos de renda, sexo e idade nas regiões brasileiras" (BRASIL, 2018a, p. 387); "Discutir e analisar as causas da violência contra populações marginalizadas (negros, indígenas, mulheres, homossexuais, camponeses, pobres etc.) com vistas à tomada de consciência e à construção de uma cultura de paz, empatia e respeito às pessoas” (BRASIL, 2018a, p. 431).

Diluídas entre as 600 páginas da BNCC, essas menções cumprem o papel de desresponsabilização, como se com isso se quisesse dizer que não se deixou de fazer algo sobre tão importante e sensível tema. Por outro lado, oferecem uma frágil brecha para a resistência ética e 
estética, para a recusa de abandonar o outro e para ajudar as crianças e jovens a construir seu Eu autêntico (GUR-ZE'EV, 2005b) e se inserir como adultos no mundo (BIESTA, 2018). Antes de retornarmos à questão da resistência, é importante analisarmos como as duas faces da BNCC se mobilizam conjuntamente em um projeto totalizante e desumanizante.

\section{A BNCC como projeto desumanizante}

Não é novidade, e nem algo necessariamente indesejável, a criação de uma Base Nacional Comum. Apple (1993), na década de 1990, analisou as propostas de teor semelhante nos Estados Unidos da América e no Reino Unido, onde também se verificaram articulações entre setores neoliberais e neoconservadores. Os argumentos em favor de uma base comum também possuem certa razoabilidade, especialmente a defesa pelo direito dos estudantes mais pobres em ter acesso aos mesmos conteúdos "básicos" que os estudantes de famílias mais ricas. Estabelecida a base, o currículo mínimo, o restante estaria aberto. É nesse "aberto" que as diferenças regionais, os interesses dos estudantes, a produção da cultura, o imprevisto etc., pode se dar. Entretanto não é isso que acontece com a BNCC. Como já afirmado, o Brasil estabeleceu no processo de redemocratização um conjunto de valores, conteúdos, temas e problemas que deveriam nortear a composição do currículo escolar. À despeito dos problemas e limitações dos PCN e das DCN, dentre os quais se destacam o boicote recíproco entre esses documentos (BONAMIGO; MARTINEZ, 2002), e a necessidade de atualização, a grande qualidade deles é que não eram obrigatórios, não eram vinculantes, não eram, portanto, normalizantes. Poderiam atuar como guias para que Estados e municípios organizassem seus currículos. Poderiam, também, servir como parâmetros para que professores realizassem suas escolhas profissionais, escolhas políticopedagógicas. Já a BNCC é declaradamente "[...] um documento de caráter normativo que define o conjunto orgânico e progressivo de aprendizagens essenciais que todos os alunos devem desenvolver ao longo das etapas e modalidades da Educação Básica” (BRASIL, 2018a, p. 7). Como Educação Normalizante estabelece a norma, o que é. Entretanto, estabelece também, pela omissão, o que não é, e, pelo silenciamento, o que não pode ser. Estabelece os valores válidos e os nãoválidos.

Além de normativa, a BNCC é declaradamente vinculante. Exige um alinhamento. A própria exigência de um alinhamento à política nacional de formação denuncia o desprezo pela pluralidade, pelas formas outras de se fazer escola. A ênfase no alinhamento não se dá apenas (o que já não é pouco), nos currículos da Educação Básica. Dá-se, também, na composição de um currículo normativo para a formação dos professores em nível superior e para a política de produção de suportes didático-pedagógicos. Conforme o documento (BRASIL, 2018a, p. 8), “[...] a BNCC integra a política nacional da Educação Básica e vai contribuir para o alinhamento de outras políticas e ações, em âmbito federal, estadual e municipal, referentes à formação de professores, à avaliação, à elaboração de conteúdos educacionais".

Não há margem efetiva de construção de uma escola diferente, atenta às especificidades do alunado, da comunidade e que, ao mesmo tempo, não se limite às suas especificidades. Em outras palavras, para uma escola que não negligencia sua realidade e que se permita contagiar pela diferença, pelo que não está na sua realidade. A política nacional não se oferece como norte, mas como norma. O alinhamento implica que o credenciamento de cursos, a concessão de bolsas, a aprovação de livros didáticos (escolhidos pelos professores após pré-seleção do poder público), etc. só ocorrerá pela submissão aos valores estabelecidos pela BNCC. É um projeto autoritário que ataca diretamente a autonomia universitária estabelecida no Art. 207 da Constituição Federal de 1988 (BRASIL, 1988). Ao reconhecer a importância dos professores para o sucesso dos estudantes (BRASIL, 2018a), o faz compreendendo o professor como mera peça do processo, estabelece, 
assim, que a primeira tarefa do projeto de alinhamento, “[...] de responsabilidade direta da União será a revisão da formação inicial e continuada dos professores para alinhá-las à BNCC" (BRASIL, 1988, p. 21). Além disso, estabelece uma rede de monitoramento para evitar quaisquer abordagens divergentes da norma. Para essa tarefa, são elencadas instituições que estiveram desde o início envolvidas com o Movimento Pela Base, como a Undime e o Consed (BRASIL, 2018a, p. 21).

Nesse espírito, o Conselho Nacional de Educação (que, importante lembrar, foi loteado no processo de elaboração da BNCC) publicou, em 20 de dezembro de 2019, a Resolução CNE/CP $\mathrm{n}^{\circ} 2$ que estabelece as Diretrizes Curriculares Nacionais para a Formação Inicial de Professores para a Educação Básica e institui a Base Nacional Comum para a Formação Inicial de Professores da Educação Básica, o que o documento chama de BNC-Formação. Como manifestação do avanço da aliança neoliberal-neoconservadora na elaboração de leis no campo educacional, a Resolução cita, no segundo parágrafo (BRASIL, 2019c, p. 1), leis de 2017 e 2018 que oferecem, segundo os autores, o suporte legal da própria Resolução. Mesmo quando cita a LBD, o faz a partir de um parágrafo, o $8^{\circ}$, acrescido ao Art. 62 por Medida Provisória, no primeiro momento, em 2016, e depois, por Lei, em 2017. Como tem se tornado corriqueiro nos processos que envolvem a legislação em torno da BNCC, o processo de elaboração da BNC-Formação foi marcado pela pressa e pela ausência de debate.

Conforme o próprio documento (BRASIL, 2019a), o texto final é o aprimoramento de uma proposta elaborada em gabinete por técnicos do MEC e apresentada em 2018. Além disso, a Resolução desconsidera as Diretrizes Curriculares Nacionais para a Formação de Professores de 2015 que, em muitas instituições, ainda estava em etapa de implementação. Em análise sobre o documento referência que embasou a BNC-Formação, a ANPEd (2019) publicou uma nota esclarecendo sua posição e elencou nove razões pelas quais a associação se opõe ao texto. Destas, destacam-se a advertência que a BNC-Formação oferece "uma formação de professores 'de uma nota só", ou seja, de que a única possibilidade de formação é a que adere à orientação dos pressupostos da BNCC, que estimula "uma formação fast food" que desprestigia a relação teoria e prática e, assim, não considera o professor como um intelectual, logo, "[...] não reconhece que o professor toma decisões curriculares" (ANPED, 2019, p. 2). Desdobramentos dessa normativa de alinhamento para a formação de professores é verificado também nos critérios de aprovação de projetos e subprojetos do Programa Interinstitucional de Bolsas de Iniciação na Docência (PIBID), no item 9.8 (BRASIL, 2020).

É nesse sentido que se afirma que a BNCC compreende o movimento da mordida de um jacaré: de uma parte normatiza um currículo limitado aos anseios neoliberais e neoconservadores para a Educação Básica; e, por outro, secundariza a formação de professores de modo que terão dificuldades de entrever alternativas político-educacionais e teóricas para além dos limites da BNCC. Os professores e as professoras, nesse caso, limitados/as a meros/as técnicos/as, têm sequestrada a dimensão intelectual de seu trabalho. Se a educação em suas versões normalizantes é tida como uma ferramenta para se atingir alguns objetivos preestabelecidos, o professor, nela, é uma peça. Como peça não tem voz. Como um boneco de ventríloquo, pela sua boca outros falam (BALL, 2012). Esses outros que falam são os interesses do mercado, a tradição inquestionável, o elaboradores da BNCC e os seus parceiros elaboradores de recursos didáticos (também alvo do alinhamento requerido no documento normativo). É a radicalização da Educação Normalizante com um verniz democrático. Pela via legal, esses movimentos antidemocráticos, de viés neoliberal e neoconservador, silenciam grupos inteiros e, dentre esses grupos, os próprios professores e estudantes.

É comum encontrar no texto referências à igualdade e à equidade (BRASIL, 2018a), seguidas dos argumentos de direito de igual acesso e de uma educação preocupada em que todos 
tenham acesso ao mesmo corpus de conhecimento. Igualdade e equidade, na BNCC, contudo, cumprem a função de cortina de fumaça para o principal valor (competência) difundido pela BNCC, fruto da articulação (às vezes tensa) entre setores neoliberais e neoconservadores: a competição (e, consequentemente, a manutenção do status quo). Compreende, então, toda a igualdade e toda a equidade possível dentro dos quadros estabelecidos do Mercado e da Moral Tradicional. O sucesso ou o fracasso da aquisição dessa competência é mensurado nos exames sistêmicos. A BNCC, com o canto da sereia da igualdade, da equidade e da democratização não oferece espaço para uma educação que não normalize, que não seja mera tecnologia para desenvolver competências preestabelecidas, sendo a principal oculta. Ao contrário, compreende um conjunto de impedimentos de uma efetiva educação, de uma educação aberta ao imprevisto, aberta à diferença, aberta ao que não é a "norma", aberta, portanto, às possibilidades de ser algo diferente do que se é. Compreende mera adaptação a um sistema já posto e tornado inquestionável e a um conjunto de valores postos e também inquestionáveis. Inclui todos os brasileiros pela exclusão da diferença. Ao defender adequações às diferentes modalidades de ensino, como a Educação Indígena, Educação de Jovens e Adultos e de Povos Remanescentes de Quilombolas (BRASIL, 2018a), o faz na defesa da criação de guetos. Não favorece o contágio com o que é outro (SAVATER, 1998). Contágio que pode iniciar pela assunção da pluralidade brasileira como um problema educacional de primeira grandeza. Como todo problema educacional, repleto de riscos e de possibilidades (BIESTA, 2017). Faz isso, portanto, apenas de forma marginal, como habilidades que, em tese, atingiriam competências. Na BNCC, a educação tem o mesmo significado que uma ferramenta qualquer. É uma tecnologia, apenas mais sofisticada que um canetão, um computador ou, mesmo, um martelo.

Ao contrário do que esperava Caimi (2016), não há lugar, na BNCC, para o novo. Sem liberdade, a educação anunciada pela BNCC é normalizante, já que é fechada para questionamento. É dessubjetivadora, já que só oferece para o indivíduo o caminho das relações instrumentais, rotineiras e mecânicas do mercado, sem margem para a criação de novas formas de se relacionar com os seus semelhantes e com os seus diferentes, a não ser dentro de uma coletividade de competidores. É, portanto, desumanizante. Nesse tipo de relação, o outro é sempre um "Isso" e nunca um "Tu" (BUBER, 2001); assim, a própria afirmação do "Eu" como um eu aberto, democrático e digno para o outro fica severamente comprometida. Os agradáveis argumentos operam como o canto de uma seria que faz da vítima a maior entusiasta de sua desumanização. Em termos educacionais, é a elevação ao extremo da constatação de Adorno e Horkheimer (1985, p. 14): "Desaparecendo diante do aparelho que serve, o indivíduo se vê, ao mesmo tempo, melhor do que nunca servido por ele". Nesse sentido, frente à educação normalizante (desumanizante) da BNCC e seus apoiadores, faz-se necessário resistir, uma forma de desobediência ética e estética ao projeto que anula a possibilidade de educação, a possibilidade de subjetivação, a criatividade que nos faz humanos e não meras peças de um sistema, por mais eficiente que seja ele.

\section{Considerações finais: o dever de resistir}

Biesta (2018) afirma que, se for preciso estabelecer uma função exclusiva da escola, uma tarefa que nenhuma outra instituição é capaz de cumprir, ela é a de resistir aos desejos indesejáveis do indivíduo, da sociedade, da família, do Estado, do mercado, da tradição etc. A educação como resistência de Biesta se aproxima demasiadamente da defesa de Gur-Ze'ev (2010a) de uma contraeducação, ou seja, de uma educação contra a educação normalizante, que, portanto, resiste a ela. Ainda de acordo com o autor, a contraeducação pode ser definida como criativa, "[...] aberta e não controlada, responsável e liberal para com a diferença do outro, dando nascimento a uma constituição que abraça o desconhecido e a autossuperação” (GUR-ZE’EV, 2010a, p. 43). 
Oferecer instrução, ensinar a competir, ensinar os valores familiares e o respeito às tradições são atribuições que outras instituições podem fazer e de uma forma melhor que a escola. Restringir a educação escolar a essa dimensão é esvaziar a escola de seu conteúdo educativo. É torná-la uma instituição obsoleta, irrelevante, na difícil e incerta tarefa de ajudar crianças e jovens a se inserir no mundo de forma adulta, a ajudar crianças e jovens na qualidade de seu crescimento enquanto seres humanos que compartilham o mundo com outros seres humanos diferentes deles próprios. É justamente em razão da força desse movimento que se apresenta com duas faces, uma neoliberal e outra neoconservadora, que oferece um discurso sedutor que apela à autoevidência de sua verdade materializada em indicadores mensuráveis, que parece ter nos engolfado e não oferece alternativas a não ser o alinhamento, que é preciso resistir. Resistir à BNCC, criar brechas pela violência transcendental da educação é, agora mais do que antes, uma responsabilidade ética e estética de todos os profissionais da educação que se recusam a ser meros técnicos, meras peças nessa maquinaria do prazer desumanizante que oferece resultados em troca da liberdade, em troca da possibilidade de ser o que ainda não se é.

É evidente que não se quer afirmar aqui que a inserção do neófito no mundo, a adaptação e a socialização, não é uma preocupação da Educação, mas tão só que a Educação precisa ser mais do que isso. Porque na tarefa de iniciar no mundo, a escola, a Educação formal, compete com várias outras instituições que possuem e procuram disseminar seus próprios valores, regras e normas de comportamento. É, então, necessário perguntar o que cabe à Educação como violência transcendental, ou seja, que desafia o sujeito sempiternamente, e o que a diferencia ou pode diferenciá-la do restante das outras formas de inserção no mundo, entre elas a educação normalizante e sua violência desumanizante (BIESTA, 2017, p. 11). Essa educação como violência transcendental, que assume a responsabilidade pela vinda do novo ao mundo, ou seja, a responsabilidade pelo novo e pelo mundo, é contraeducação, uma forma de ação no mundo que não sequestra o futuro e pode, assim, como sustenta Gur-Ze'ev (2005b, p. 160), nos ajudar a promover uma forma de recusa solidária do poder, da ideia de lar e de identidade que se manifesta pela rejeição da outridade em direção a uma ação ético-estética do ser-no-mundo-como-tornandose-presença, como tornando-se um Eu autêntico.

A resistência à BNCC é uma responsabilidade ética porque estabelece de partida o nãomais, aquilo de que é preciso resistir: a normalização desumanizante de indivíduos impedidos de ser algo ainda imprevisto, indivíduos que não consideram a liberdade uma possibilidade (salvo a escassa margem de movimentação autorizada pelo mercado e pela tradição). É estética porque significa uma forma de Ser-uma-presença-no-mundo aberta à incerteza do vir-a-Ser, aberta à superação da normalização e da rotinização das relações com o outro. Não apenas aceita o outro, o tolera e o aceita como adversário no mercado, mas o deseja, deseja a outridade como riqueza e se oferece como outridade para o outro, o companheiro para compartilhar o mundo, seus problemas e suas possibilidades, em uma forma de conviver junto (BIESTA, 2018).

Como sempre, quando se fala de efetiva educação, não se pode oferecer certeza de que a resistência obterá sucesso. Especialmente frente a tão bem articulado movimento normalizante. Não se dispõe aqui de recursos mensuráveis, sobretudo porque se recusa a rebaixar a educação a mera tecnologia, a mero serviço a ser prestado. Embora não se possa oferecer a certeza do sucesso, tem-se a certeza do dever ético e estético de quem ainda não desistiu, de quem ainda vê o mundo como um lugar para compartilhar e que vê o outro não como um adversário contra quem competir ou como um objeto de curiosidade, mas como um companheiro digno para compartilhar o próprio mundo. De quem ainda deseja ser um companheiro digno para o outro. De quem ainda acredita na Educação. 


\section{Referências}

ADORNO, T.; HORKHEIMER, M. Dialética do Esclarecimento. Rio de Janeiro: Zahar, 1985.

ANPED. Associação Nacional de Pós-Graduação e Pesquisa em Educação. Uma formação formatada. Posição da ANPED sobre o "Texto Referência - Diretrizes Curriculares Nacionais e Base Nacional Comum para a formação inicial e continuada de professores da Educação Básica". ANPEd, 2019.2 Disponível em: $<$ http://www.anped.org.br/sites/default/files/images/posicao_da_anped_sobre_o_texto_refere ncia_diretrizes_curriculares_nacionais_e_base_nacional_comum_para_a_formacao_inicial_e_co ntinuada_de_professores_da_educ.pdf $>$. Acesso em: 22 fev. 2020.

ANPED; ABDC. Associação Nacional de Pós-Graduação e Pesquisa em Educação. Associação Brasileira de Currículo. Ofício n. ${ }^{\mathbf{0}}$ 01/2015/GR. Exposição de Motivos sobre a Base Nacional Comum Curricular. 2015. Disponível em: <https://avaliacaoeducacional.files.wordpress.com/2015/12/posicionamentobncanpedeabdc.pdf>. Acesso em: 20 fev. 2020.

ANPUH. Associação Nacional de História. Nota sobre a Segunda Versão da BNCC. 2016. Disponível em: <https://anpuh.org.br/index.php/2015-01-20-00-0155/noticias2/diversas/item/3574-nota-sobre-a-segunda-versao-da-bncc $>$. Acesso em: 19 nov. 2019.

ANTUNES, M. F. S. O currículo como materialização do Estado gerencial: a BNCC em questão. Movimento-Revista de Educação, Niterói, v. 6, n. 10, p. 43-64, jan./jun. 2019. DOI: https://doi.org/10.22409/mov.v0i10.517

APPLE, M. W. The politics of official knowledge: Does a national curriculum make sense? Teachers College Record, Columbia, v. 95, n. 2, p. 222-241, 1993. DOI: https://doi.org/10.1080/0159630930140101

ARENDT, H. A condição humana. Rio de Janeiro: Forense Universitária, 2017.

ARENDT, H. Entre o passado e o futuro. São Paulo: Perspectiva, 2016.

ARENDT, H. The origins of totalitarianism. New York: Harcount, Brace \& Co., 1973.

AVELAR, M.; BALL, S. J. Mapping new philanthropy and the heterarchical state: The Mobilization for the National Learning Standards in Brazil. International Journal of Education Development, v. 64, p. 65-73, jan. 2017. DOI: https://doi.org/10.1016/j.ijedudev.2017.09.007

BALL, S. J. Reforma educacional como barbárie social: economismo e o fim da autenticidade. Práxis Educativa, Ponta Grossa, v. 7, n. 1, p. 33-52, jan./jun. 2012. DOI: https://dx.doi.org/10.5212/PraxEduc.v.7i1.0002

BARBOSA, I. G.; SILVEIRA, T. A. T. M.; SOARES, M. A. A BNCC da Educação Infantil e suas contradições: regulação versus autonomia. Retratos da Escola, Brasília, v. 13, n. 25, p. 77-90, jan./maio 2019. DOI: https://dx.doi.org/10.22420/rde.v13i25.979

BAUMAN, Z. Estranhos à nossa porta. Rio de Janeiro: Zahar, 2017.

BIESTA, G. Good Education in an Age of Measurement. Educational Assessment, Evaluation and Accountability [online], v. 21, n. 1. p. 33-46, fev. 2009. DOI: https://doi.org/10.1007/s11092$\underline{008-9064-9}$ 
BIESTA, G. O dever de resistir: sobre escolas, professores e sociedade. Educação, Porto Alegre, v. 41, n. 1, p. 21-29, jan./abr. 2018. DOI: https://doi.org/10.15448/1981-2582.2018.1.29749

BIESTA, G. Para além da aprendizagem: educação democrática para o futuro humano. Belo Horizonte: Autêntica, 2017.

BONAMIGO, A.; MARTINEZ, S. A. Diretrizes e Parâmetros Curriculares Nacionais para o Ensino Fundamental: a participação das instâncias políticas do Estado. Educação \& Sociedade, Campinas, v. 23, n. 80, p. 368-385, set. 2002.

BRASIL. [Constituição (1988)]. Constituição da República Federativa do Brasil. Brasília, DF: Senado, 1988.

BRASIL. Decreto 10.004, de 5 de setembro de 2019b. Institui o Programa Nacional das Escolas Cívico-Militares. Brasília: Presidência da República, Casa Civil, Subchefia para Assuntos Jurídicos, Brasília: Câmara de Deputados, [2019b]. Disponível em: <https://www2.camara.leg.br/legin/fed/decret/2019/decreto-10004-5-setembro-2019-789086publicacaooriginal-159009-pe.html>. Acesso em: 30 mar. 2020.

BRASIL. Lei No 9.394, de 20 de dezembro de 1996. Estabelece as diretrizes e bases da educação nacional. Diário Oficial da União: seção 1, Brasília, DF, n. 248, p. 27833-27841, 23 dez. 1996.

BRASIL. Lei $\mathrm{N}^{\circ}$ 13.415, de 16 de fevereiro de 2017. Altera as Leis $\mathrm{N}^{\text {os }} 9.394$, de 20 de dezembro de 1996, que estabelece as diretrizes e bases da educação nacional, e 11.494, de 20 de junho 2007, que regulamenta o Fundo de Manutenção e Desenvolvimento da Educação Básica e de Valorização dos Profissionais da Educação, a Consolidação das Leis do Trabalho - CLT, aprovada pelo Decreto-Lei no 5.452, de 1 o de maio de 1943, e o Decreto-Lei no 236, de 28 de fevereiro de 1967; revoga a Lei no 11.161, de 5 de agosto de 2005; e institui a Política de Fomento à Implementação de Escolas de Ensino Médio em Tempo Integral. Diário Oficial da União: seção 1, Brasília, DF, n. 35, p. 1-3, 17 fev. 2017a.

BRASIL. Ministério da Educação. Base Nacional Comum Curricular: versão para consulta pública. Brasília: $\quad$ MEC, 2015.2 Disponível em: <https://historiadabncc.mec.gov.br/documentos/BNCC-APRESENTACAO.pdf>. Acesso em: 19 nov. 2019.

BRASIL. Ministério da Educação. Base Nacional Comum Curricular: segunda versão revista. Brasília: MEC, 2016a. Disponível em: <https://historiadabncc.mec.gov.br/documentos/bncc2versao.revista.pdf>. Acesso em 19 nov. 2019.

BRASIL. Ministério da Educação. Base Nacional Comum Curricular: consulta pública concluída! 2016b. Disponível em: < https://historiadabncc.mec.gov.br/\#/site/fim-contribuicao>. Acesso em: 19 nov. 2019.

BRASIL. Ministério da Educação. Base Nacional Comum Curricular: educação é a base. Brasilia: MEC, 2018a. Disponível em: $<$ https://basenacionalcomum.mec.gov.br/images/BNCC_EI_EF_110518_versaofinal_site.pdf >. Acesso em: 10 dez. 2020.

BRASIL. Ministério da Educação. Etapa do ensino médio é homologada e Base Nacional Comum Curricular está completa. 2018b. Disponível em: <https://portal.mec.gov.br/component/content/article?id=72011>. Acesso em: 28 nov. 2019. 
BRASIL. Projeto de Lei $\mathbf{n}^{\mathbf{0}} \mathbf{2 4 0 1 / 2 0 1 9}$. Dispõe sobre o exercício do direito à educação domiciliar, altera a Lei $\mathrm{n}^{\circ}$ 8.069, de 13 de julho de 1990 - Estatuto da Criança e do Adolescente, e a Lei $\mathrm{n}^{\circ}$ 9.394, de 20 de dezembro de 1996, que estabelece as diretrizes e bases da educação nacional. Brasília: Câmara de Deputados, [2019a]. Disponível em: <https://www.camara.leg.br/proposicoesWeb/prop_mostrarintegra;jsessionid=F59BA458E5C D348ADFF5846C1677FCEF.proposicoesWebExterno1? codteor $=1734553 \&$ filename $=$ PL +2401 /2019>. Acesso em: 30 mar. 2020.

BRASIL. Resolução CNE/CP No 2, de 22 de dezembro de 2017. Institui e orienta a implantação da Base Nacional Comum Curricular, a ser respeitada obrigatoriamente ao longo das etapas e respectivas modalidades no âmbito da Educação Básica. Brasília: Ministério da Educação, Conselho Nacional de Educação, Conselho Pleno, [2017b]. Disponível em: <http://basenacionalcomum.mec.gov.br/images/historico/RESOLUCAOCNE_CP222DEDE ZEMBRODE2017.pdf>. Acesso em: 10 dez. 2019.

BRASIL. Resolução $\mathbf{N}^{\circ}$ 2, de 20 de dezembro de 2019. Define as Diretrizes Curriculares Nacionais para a Formação Inicial de Professores para a Educação Básica e institui a Base Nacional Comum para a Formação Inicial de Professores da Educação Básica (BNC-Formação). Brasília: Ministério da Educação, Conselho Nacional de Educação, Conselho Pleno, [2019c]. Disponível em:

$<$ https://apoiocoordenadoriascursosgraduacao.paginas.ufsc.br/files/2020/01/Resolu\%C3\%A7 \%C3\%A3o-CNE_CP-2_20dez2019.pdf>. Acesso em: 30 mar. 2020.

BRASIL. Programa Institucional de Bolsa de Iniciação à Docência - PIBID. Edital n ${ }^{\circ}$ 2/2020. $\quad 2020 . \quad$ CAPES, Disponível em <https://www.capes.gov.br/images/novo_portal/editais/editais/06012019-EDITAL-2-2020PIBID.pdf $>$. Acesso em: 20 fev. 2020.

BUBER, M. Eu e Tu. São Paulo: Centauro, 2001.

CAIMI, F. E. A História na Base Nacional Comum Curricular: pluralismo de ideias ou guerra de narrativas? Revista do Lhiste, Porto Alegre, v. 3, n. 4, p. 86-92, jan./jun. 2016.

CALDEIRA NETO, O. Frente nacionalista, neofascismo e novas "direitas" no Brasil. Faces de Clio, Juiz de Fora, v. 2, n. 4, p. 20-36, jul./dez. 2016.

CAMPBELL, C.; SHERINGTON, G. The comprehensive public High School: historical perspectives. New York: Palgrave Macmillan, 2006.

CARTER, L.; DEDIWALAGE, R. Globalisation and science education: The case of sustainability by the bay. Cultural Studies of Science Education, v. 5, n. 2, p. 275-291, jun. 2010. DOI: https://doi.org/10.1007/s11422-009-9248-8

CASANOVA, L. V.; FERREIRA, V. S. Os discursos da Associação Nacional de Educação Domiciliar do Brasil. Práxis Educativa, Ponta Grossa, v. 15, n. 1, p. 1-17, 2020. DOI: https://doi.org/10.5212/PraxEduc.v.15.14771.025

CECHETTI, E.; TEDESCO, A. L. Educação Básica em "xeque": Homeschooling e fundamentalismo religioso em tempos de neoconservadorismo. Práxis Educativa, Ponta Grossa, v. 15, n. 1, p. 1-17, 2020. DOI: https://doi.org/10.5212/PraxEduc.v.15.14816.026 
CONNELL, R. The neoliberal cascade and education: An essay on the market agenda and its consequences. Critical Studies in Education, Londres, v. 54, n. 2, p. 99-112, 2013. DOI: https://doi.org/10.1080/17508487.2013.776990

FOUCAULT, M. The birth of biopolitics: Lectures at the Collège De France, 1978-79. New York: Palgrave Macmillan, 2008.

FREITAS, L. C. Responsabilização, meritocracia e privatização: como conseguiremos escapar ao neotecnicismo? In: PINO, I. R.; PACHECO, D. D. (Orgs.). Plano Nacional de Educação (PNE): questões desafiadoras e embates emblemáticos. Brasília: INEP, 2013. p. 47-84.

GALLI, V. Nota de esclarecimento. 2017. Disponível em <https://www.facebook.com/VictorioGalliOficial/posts/1229432640488283:0>. Acesso em: 15 out. 2017.

GGN. Grupo Gente Nova. Para conservadores ideologia de gênero é marxista e não cabe no Plano Nacional de Educação. 2014. Disponível em: $<$ https://jornalggn.com.br/noticia/para-conservadoresideologia-de-genero-e-marxista-e-naocabe-no-plano-de-educacao >. Acesso em: 5 set. 2016.

GOSPELMAIS. Marco Feliciano reafirma que não renunciará, fala sobre aborto e diz que movimento LGBT quer impor uma "ditadura gay" no Brasil. 2013. Disponível em: $<$ https://www.noticias.gospelmais.com.br/marco-feliciano-movimento-lgbt-imporditadura-gaybrasil-52188.html>. Acesso em: 5 set. 2016.

GUILHERME, A. A.; PICOLI, B. A. Escola sem Partido: elementos totalitários em uma democracia moderna - uma reflexão a partir de Arendt. Revista Brasileira de Educação, Rio de Janeiro, v. 23, n. 42, 2018. DOI: https://dx.doi.org/10.1590/S1413-24782018230042

GUILHERME, A. A.; PICOLI, B. A. Neoliberalism and Education in the Global South: A New Form of Imperialism. In: NESS, I.; COPE, Z. (eds.) The Palgrave Encyclopedia of Imperialism and Anti-Imperialism. Londres: Palgrave Macmillan: 2019. p. 1-13.

GUILHERME, A. A.; PICOLI, B. A. Redes sociais e educação informal: entre o scemo del villaggio e o pensamento crítico. Diálogos Latinoamericanos, Aarhus, Dinamarca, v. 26, p. 2337, 2017.

GUR-ZE'EV, I. Adorno and Horkheimer: Diasporic Philosophy, Negative Theology, and Counter education. Educational theory, Illinois, v. 55, n. 3, 343-365, 2005a. DOI: https://doi.org/10.1111/j.1741-5446.2005.00007.x

GUR-ZE'EV, I. Beyond postmodern feminist Critical Pedagogy: Toward a Diasporic philosophy of conter-education. In: GUR-ZE'EV, I. (Org.). Critical theory and critical pedagogy today: toward a new critical language in education. Haifa: Universidade de Haifa, 2005b. p. 160-192.

GUR-ZE'EV, I. Diasporic Philosophy, Counter-Education and Improvisation, Studies in Philosophy and Education, 28, p. 386-381, 2007. DOI: https://doi.org/10.1007/s11217-007$\underline{9081-z}$

GUR-ZE’EV, I. É possível uma educação crítica no ciberespaço? Comunicações, Piracicaba, v. 9, n. 1, 72-98, jun. 2002. DOI: https://dx.doi.org/10.15600/2238-121X/comunicacoes.v9n1p72$\underline{98}$ 
GUR-ZE'EV, I. The Nomadic existence of the eternal improviser and diasporic co-poiesis today. In: GUR-ZE'EV, I. (Org.). Diasporic Philosophy and Counter Education. Rotterdan: Sense Publishers, 2010a. p. 29-46.

GUR-ZE'EV, I. The possibility/impossibility of a new critical language in education. Rotterdan: Sense Publishers, 2010b.

HYPOLITO, Á. M. BNCC, agenda global e formação docente. Retratos da Escola, Brasília, v. 13, n. 25, p. 187-201, jan./maio 2019. DOI: http://dx.doi.org/10.22420/rde.v13i25.995

KARLSSON, S. The north-south knowledge divide: Consequences for global environmental governance. In: ESTY, D.; IVANOVA, M. (Orgs.), Global environmental governance options \& opportunities. New Haven: Yale School of Forestry \& Environmental Studies, 2002. p. 53-76.

KAŠČÁK, O.; PUPALA, B. Governmentality - neoliberalism - education: The risk perspective. Journal of Pedagogy, v. 2, n. 2, p. 145-158, 2011. DOI: https://doi.org/10.2478/v10159-011$\underline{0007-z}$

LILA, M. A mente naufragada: sobre o espírito reacionário. Rio de Janeiro: Record, 2018.

LÖWY, M. Conservadorismo e extrema-direita na Europa e no Brasil. Serviço Social e Sociedade, São Paulo, n. 124, p. 652-664, out./dez. 2015. DOI: https://doi.org/10.1590/0101$\underline{6628.044}$

MANCEBO, D. Indivíduo e psicologia: gênese e desenvolvimento atuais. In: MANCEBO, D.; VILELA, A. M. J. (Orgs.). Psicologia Social: abordagens sócio-históricas conceituais e desafios contemporâneos. 2. ed. Rio de Janeiro: EDUERJ, 2004. p. 35-48.

MCLAREN, P.; FARAHMANDPUR, R. The globalization of capitalism and the new imperialism: Notes towards a revolutionary critical pedagogy. Review of Education, Pedagogy, and Cultural Studies, v. 23, n. 3, 271-315, 2001. DOI: https://doi.org/10.1080/1071441010230304

MCMURTRY, J. The cancer stage of capitalism. London: Pluto Press, 1999.

MENDONÇA, E. F. Escolas cívico-militares: cidadão ou soldadinhos de chumbo? Retratos da Escola, Brasília, v. 13, n. 27, 2019. DOI: https://dx.doi.org/10.22420/rde.v13i27.1039

MOVIMENTO PELA BASE. Quem Somos. 2017. Disponível em <https://movimentopelabase.org.br/quem-somos/>. Acesso em: 19 nov. 2019.

NEITZEL, Odair; SCHWENGBER, Ivan Luís. Os conceitos de capacidade, habilidade e competência e a BNCC. Revista Educação e Emancipação, Maranhão, v. 12, n. 2, p. 210-227, maio./ago. 2019. DOI: https://dx.doi.org/10.18764/2358-4319.v12n2p210-227

O ESTADO DE SÃO PAULO. Deputado federal diz que Mickey é homossexual e que Disney faz apologia ao 'gayzismo'. Estadão, 13 mar. 2017. Disponível em $<$ https://emais.estadao.com.br/noticias/comportamento,deputado-federal-diz-quemickeyehomossexual-e-que-disney-faz-apologia-ao-gayismo>. Acesso em: 15 out. 2017.

OLSSEN, M.; PETERS, M. A. Neoliberalism, Higher Education and the knowledge economy: From the free market to knowledge capitalism. Journal of Education Policy, Londres, v. 2, n. 3, p. 313-345, 2005. DOI: https://doi.org/10.1080/02680930500108718 
PENNA, F. A. Programa Escola sem Partido: uma ameaça à educação emancipadora. In: GABRIEL, C. T.; MONTEIRO, A. M.; MARTINS, M. L. B. (Orgs.). Narrativas do Rio de Janeiro nas aulas de História. Rio de Janeiro: Mauad, 2016. p. 43-58.

PENNA. F. A. Sobre o ódio ao professor entrevista com Fernando Penna. Movimento-Revista de Educação, Niterói, v. 3, p. 294-301, 2015. DOI: https://doi.org/10.22409/mov.v0i3.275

PETERS, M. Education, enterprise culture and the entrepreneurial self: A Foucauldian perspective. Journal of Educational Enquiry [online], v. 2, n. 2, p. 58-71, 2001.

PICOLI, B. A. Homeschooling e os irrenunciáveis perigos da educação: reflexões sobre as possibilidades de educação sem escola no mundo plural a partir de Arendt, Biesta e Savater. Práxis Educativa, Ponta Grossa, v. 15, n. 1, p. 1-22, 2020. DOI: https://doi.org/10.5212/PraxEduc.v.15.14535.023

PONGRATZ, L. A. Voluntary self-control: Education reform as a governmental strategy. Educational Philosophy and Theory, Oxford, v. 38, n. 4, p. 471-482, 2006. DOI: https://doi.org/10.1111/j.1469-5812.2006.00205.x

PORTAL EBC. Conselho Nacional de Educação é órgão independente; entenda a função. Disponível em: <https://www.ebc.com.br/educacao/2016/06/entenda-o-que-e-o-conselhonacional-de-educacao-e-por-que-ele-e-importante>. Acesso em: 15 jan. 2020.

ROMANCINI, R. Do "Kit Gay" ao "Monitor da Doutrinação": a reação conservadora no Brasil. Contracampo, Niterói, v. 37, n. 2, 2018. DOI: https://doi.org/10.22409/contracampo.v0i0.1102

SAVATER, F. O valor de educar. São Paulo: Martins Fontes, 1998.

SAVIANI, D. Educação escolar, currículo e sociedade: o problema da Base Comum Curricular. Movimento-Revista de Educação, Niterói, v. 3, n. 4, 2016. DOI: https://doi.org/10.22409/mov.v0i4.296

SILVA, S. G.; CANTARELLI, J. M. Justiça social e discurso neoliberal: problematizações sobre a base nacional comum curricular. Espaço Pedagógico, Passo Fundo, v. 26, n. 3, p. 777-794, 2019. DOI: https://doi.org/10.5335/rep.v26i3.9267

VASCONCELOS, M. C. C.; BOTO, C. A educação domiciliar como alternativa a ser interrogada: problema e propostas. Práxis Educativa, Ponta Grossa, v. 15, n. 1, p. 1-21, 2020. DOI: https://doi.org/10.5212/PraxEduc.v15.14654.019

ZANOTTO, M.; SANDRI, S. Avaliação em larga escala e BNCC: estratégias para o gerencialismo na educação. Temas \& Matizes, Cascavel, v. 12, n. 23, p. 127-143, jul./dez. 2018.

Recebido em 10/01/2020

Aceito em 25/03/2020

Publicado online em 01/04/2020 